\title{
NATURAL GAS REGULATION UNDER THE HOLDING COMPANY ACT
}

\author{
Ralph K. HuitT*
}

INTRODUCTION

The Public Utility Holding Company Act of $1935^{1}$ was designed to eliminate abuses shown, by extensive studies made for the Congress, ${ }^{2}$ to exist in holding company operations in the electric power and natural gas industries. The provisions of the Act fall into two basic categories. The first requires the geographic integration and corporate simplification of utility holding company systems, with broad powers vested in the Securities and Exchange Commission to carry out the legislative mandate. The primary purpose of these provisions is to reduce the holding company systems through national action to such size that the states can regulate them effectively. The second consists of supervisory powers assigned to the Commission over the finances and operations of holding company systems, which are intended to supplement and strengthen state regulation. The Act is unique in American regulatory history in that it directs an administrative agency to break up existing business organizations and to reconstruct two industries to conform with a pattern drawn by the legislature. It has worked far-reaching changes in the structure and practices of both industries. This study will be concerned with the impact of the Act on the natural gas industry, the administrative performance of the Commission in its ground-breaking task, and the implications of the regulatory experience under the Act for other sectors of the economy.

\section{A. Background for Regulation}

Perhaps the outstanding characteristic of the natural gas industry in 1935 was its astonishingly rapid physical growth, with five times as much gas marketed in the peak year of 1930 as in 1906. An increasingly large proportion of this burgeoning industry was being parceled out among a relatively small number of powerful

* A.B. 1934, Southwestern University; Ph.D. I950, University of Texas. Assistant Professor of Political Science, University of Wisconsin, since 1949. Faculty Fellow, The Fund for the Advancement of Education (Ford Foundation), I953-54. Contributor to legal and political science journals.

149 STAT. 803, I5 U. S. C. $\$ 79$.

2 Utility Corporations, Report of the federal Trade Commission to the Senate of the United States (96 vols.), Sen. Doc. No. 92, 7oth Cong., ist Sess. (1935) (see especially A Summary Report on Holding and Operating Companies, No. 72-A, and Final Report on Economic, Corporate, Operating, and Financial Phases of the Naturaz-Gas Producing, Pipe-Line, and Utility Industries, With Conclusions and Recommendations, No. 84-A); Report of the Relation of Holding Companies to Operating Companies in Power and Gas Affecting Control (6 vols.), H. R. Rep. No. 827, 73d Cong., $2 \mathrm{~d}$ Sess. (r935). See also Hearings before the Committee on Interstate and Foreign Commerce on H. R. 5423 (3 vols.), 74th Cong., Ist Sess. (1936); Hearings before the Committee on Interstate Commerce on $S$. 1725, 74th Cong., Ist Sess. (1936). 
groups. Among the groups exercising progressively more concentrated control, the most important were Electric Bond and Share Company, Cities Service Company, Columbia Gas and Electric Corporation, and Standard Oil Company (New Jersey). Among them they controlled approximately I8 per cent of gas production, $5^{6}$ per cent of the pipe lines, and 60 per cent of the interstate movement of gas. Control of interstate pipe line transportation was the key to dominance over the industry; there was no alternative mode of transportation, and in 1935 the interstate movement of gas was not regulated. The four giants, with six other companies, controlled 86 per cent of the interstate movement of gas in $19344^{8}$

The holding company was the chosen instrument of control. It offered a rich diversity of devices by which a relatively small investment could be made to control a vast agglomeration of physical property and reap the profit therefrom. The possibilities invited artistic improvisation: H. C. Hopson, the virtuoso of Associated Gas and Electric, offered securities tailor-made for every kind of investor-except the one who wanted a voice in the management of the business. ${ }^{4}$ But the finest flower of the holding company era was the pyramid. The procedure for constructing a pyramid was to sell the bonds and preferred stock of an operating company to the public and to buy the voting common stock for a sub-holding company, which in turn sold its bonds and preferred to the public and its common stock to the next level holding company. This could go on; Hopson had twelve companies in one chain of control in his Associated Gas and Electric pyramid.5 This procedure shifted the risk to the investing public and greatly increased the profits and power of the control group. But it was a fair weather structure. The only wealth-producing unit in the pyramid was the operating company; when its earnings declined, those of the holding companies vanished. Thus it was that more than 90 electric and gas companies were placed in receivership or declared bankrupt between 1929 and $1935^{\circ}$

The Federal Trade Commission's investigation of utility corporations disclosed a number of specific abuses. Among them were substantial "write-ups," representing no actual investment, in the capital assets of companies examined, amounting to I3.8 per cent of total assets of holding companies, and I4.8 per cent of assets of operating companies. ${ }^{7}$ The practical effect of these inflated capital structures was to encourage dubious business and accounting practices in order to maintain dividend payments. Again, holding companies frequently exploited subsidiaries under the guise of performing financial and management services. Most of the services were genuine; the question was whether the holding company charged for them fairly. Interest rates usually were high, and sometimes compounded monthly. The compensation for management services was determined by contract between the utility and the servicing organization, and often was quite high, "yielding a net profit of more than I0o percent on servicing costs, and very much more in some

\footnotetext{
${ }^{3}$ Utility Corporations, Sen. Doc. No. 92, op. cit. supra note 2, No. 84-A, at 28-39.

4Id. No. 72-A, at 136-154. ${ }^{5} \mathrm{Id}$. at 154-166.

idd. at 154 n. 46 .

'Id. at $154-166$.
II. $84-A$, at 296-297.
} 
instances." 8 No competitive rates were available to operating companies because the holding companies had preempted the servicing field.

Some specific services justly could be claimed by the holding company, but over against them could be marshaled a formidable list of abuses. The pressure to meet fixed charges and pay dividends on top-heavy capital structures brought a train of evils: high rates, milking of subsidiaries, stock market manipulation, dividends paid out of capital or unearned surplus, inadequate depreciation reserves-the Federal Trade Commission listed ig "questionable practices" which were common. These were not considered to be just matters of poor business judgment. The Commission said: ${ }^{9}$

... the use of words such as fraud, deceit, misrepresentation, dishonesty, breach of trust, and oppression are the only suitable terms to apply if one seeks to form an ethical judgment on many practices which have taken sums beyond calculation from the rate paying and investing public.

\section{B. Significance of the Act}

It will be helpful to precede a more detailed examination of the administration of the Holding Company Act with a brief summary of its purpose and provisions. The Act applies to holding companies having subsidiaries which are electric utility companies or which are engaged in the retail distribution of natural or artificial gas. The express purpose of the Act is to eliminate those abuses which were revealed by the investigations of holding companies undertaken at the direction of Congress. Public utility holding companies are required to register with the Securities and Exchange Commission, which has power under specified conditions to make exemptions. The most important duty of the Commission is to require the geographic integration and corporate simplification of public utility holding company systems, limiting pyramiding to the second degree and requiring an equitable distribution of the voting power among security holders. The Commission also must pass upon reorganization plans of registered holding company systems. The Commission is charged with the supervision of three kinds of activities: (I) security transactions of holding companies and their subsidiaries; (2) acquisition of securities, assets, and other interests by holding companies and their subsidiaries; (3) payment of dividends, solicitation of proxies, intercompany loans, and service, sales and construction contracts. The Commission may prescribe uniform accounts and require reports. The Act is designed to protect both investors and consumers.

The central interest of the Holding Company Act lies in the attempt by the public through government to work a major revolution in the structure and behavior of private business. This was not the first time, to be sure, that such an attempt had been made. The significance of the Holding Company Act consists not so much in the principles which it espouses as in the techniques which it employs. The antitrust acts had declared certain kinds of corporate organizations and

${ }^{8} I d$. at 55 I.

Id. No. $73-\mathrm{A}$, at $62-63$. 
practices to be inimical to the public interest and had granted to public agencies the power to prevent them--even to the extent of dissolving business groups and forcing divestiture of property. But the antitrust laws stemmed from the common law. They depended for enforcement on the policeman and the lawsuit. In practice the courts had proved timid about breaking up established corporate structures and organizationally incompetent to supervise adequately the carrying out of such dissolution decrees as they did hand down. Nor have the courts availed themselves of the services of the Federal Trade Commission to help with enforcement of decrees.

The methodology established in the Holding Company Act is quite different from the antitrust laws; it is the administrative, as opposed to the common law, approach. The antitrust laws abound in the generalities of the common law, e.g., "combination in restraint of trade" and "unfair competition." The wording of the Sherman Act has been said to have "a generality and adaptability comparable to that found to be desirable in constitutional provisions." ${ }^{\text {"10 }}$ More precise definitions must wait upon prosecutions which explore the periphery of practice. ${ }^{11}$ The Holding Company Act, on the other hand, marks off a precise area of application; it gives to an administrative agency a concrete picture of the kind of business reorganization that Congress wishes to achieve within that area, but leaves to the agency much discretion in the manner and degree of its accomplishment; and it gives to the rules, regulations, and orders of the agency a validity which the appellant must disprove. In carrying out its tasks the agency may use a wide range of tools and talents; accountants, economists, engineers, and lawyers pool their efforts. An examination of the books is as good, or better, evidence than sworn testimony. The agency goes to court only as a last resort; its first task is to seek voluntary compliance with the law. Further, it may make sure through continuous supervision that compliance is genuine and consistent.

The Holding Company Act in I935 promised a fair test of the efficiency of the administrative process in the delicate task of reshaping a part of the economy. The statute was clear, the Commission's power ample. The political climate of the day supported reform, and by 1938 , when the Commission was to begin serious efforts under the Act, the Court was prepared to be sympathetic. The President was to send to the Commission some of the ablest men to serve the New Deal. Much of the interest in this study therefore will center in the many-fronted effort of the Commission to refashion the industries in its charge. A liquidation proceeding to eliminate a functionless tier in a pyramid, for instance, may also be used to improve the capital structure of an associated company. The success of grand strategy depends ultimately upon tactics. The Commission has made progress in its principal task largely because of its tidy sense of the relatedness of all its actions. The principal concern of this study will be with the natural gas industry, but it will not be possible to separate it, in many aspects of the Commission's regu-

${ }^{10}$ Appalachian Coals, Inc. v. United States, 288 U. S. 344,360 (1933).

${ }^{11}$ Hamilton and Till, ANtTtrust in Action (TNEC Monograph 16, 1940). 
latory activities, from the electric power industry. The two industries were intertwined in I935; the Act covers them both; and so a decision in a case involving one establishes principles for both.

\section{Constitutionality of the Act}

It is a common experience for the administration of an important regulatory act to be held up until every important section of it has been tested in the courts. The Public Utility Holding Company Act has the unusual record of having effected very wide changes in the structure and conduct of hundreds of holding companies and their subsidiaries before the Supreme Court ever ruled upon its most important section.

Very soon after its passage, the Act was smothered under lawsuits, despite the assurances of the Securities and Exchange Commission and the Attorney General that no penalties would be invoked for failure to comply with the Act until a test case brought against the Electric Bond and Share Company had been decided. The government successfully sought to confine this case to a test of Sections $4(a)$ and 5 which require the registration of holding companies subject to the Act. All three levels of courts agreed that the registration provisions were separable from the other provisions of the Act, that they were the only provisions which presented a justiciable controversy, and that they constituted a valid exercise by Congress of its power over interstate commerce and the mails. ${ }^{12}$

The Electric Bond and Share decision was decisive in putting into effect the Act's provisions. Within a year the value of holding company assets registered under the Act increased approximately 215 per cent. ${ }^{13}$ Eight years were to elapse before the Court ruled on the vital Section $I I$ provisions. Section $\operatorname{Ir}(b)(x)$, requiring geographic integration of holding companies, was upheld on April I, r946, as a valid exercise of Congressional power over interstate commerce and the mails; ${ }^{14}$ and a similar validity was attributed to Section $\mathrm{II}(\mathrm{b})(2)$, prescribing corporate simplification, on November 25, 1946..$^{15}$ By this time holding companies in Section II proceedings had divested interests in 399 subsidiaries having aggregate assets of more than six billion dollars. ${ }^{16}$

\section{II}

\section{INTERPRETATION AND AdMINISTRATION OF SECTION II}

All of the Holding Company Act except Section II is designed to regulate the future activities of companies subject to the Act; Section II directs the Commission to undo what is already done. Section II(a) requires the Commission to study every holding company system to determine what may be done to it to reshape it to fit the purposes of the Act. Section $\mathrm{II}(\mathrm{b})(\mathrm{I})$ directs the Commission to reduce

${ }^{12}$ SEC v. Electric Bond \& Share Co., 18 F. Supp. I3I (S. D. N. Y. I937), aff'd, 92 F. 2d 580 (2d Cir. 1937), affd, 303 U. S. 419 (1938).

${ }^{13}{ }_{4}$ SEC ANN. Rep. 6-8 (1938).

14 North American Co. v. SEC, 327 U. S. 686 (1946).

${ }^{15}$ American Power \& Light Co. v. SEC, 329 U. S. 9o (1946).

${ }^{20} 12$ SEC ANN. REP. 47 (1946). 
holding company systems to one or more integrated systems and to such additional businesses as may be reasonably incidental or economically necessary or appropriate to the operations of the integrated systems. Section II(b)(2) requires elimination of unnecessary complexities in corporate structures of holding company systems and the redistribution of voting power fairly and equitably among their security holders. Pyramiding to the second degree is established as the extreme limit of complexity of corporate structures. The other provisions of the Section are related to the carrying out of the requirements of Section $\operatorname{II}(b)$. Section $\operatorname{II}(e)$ provides that any registered holding company or any subsidiary of such a company may submit a plan to the Commission, for its approval, in voluntary compliance with the requirements of Section II(b). Section II(f) requires that reorganization plans of registered holding companies or subsidiaries under consideration in federal courts be approved by the Commission before becoming effective.

\section{A. Some Interpretations}

A proviso to Section $\operatorname{II}(\mathrm{b})$ (I) allows a holding company to continue to control one or more additional integrated public-utility systems if each meets three requirements: (A) it cannot be operated as an independent system without the loss of substantial economies secured by holding company control; (B) all systems are located in one state or adjoining states, or in contiguous foreign country; and (C) the combination is not so large as to impair the advantages of localized management, efficient operation, or the effectiveness of regulation. Columbia Gas and Electric Co. sought to retain both gas and electric utilities as components in a single integrated system, declining to present evidence that either met the standards for retention of an additional system. The Commission held that one must be designated as the holding company's integrated system; the other may be kept then only if it qualifies as an additional system. ${ }^{17}$ In an earlier case, an electric system had been permitted to retain a gas utility system that was small enough to qualify. ${ }^{18}$ The Commission rejected a "two area" interpretation of clause (B) offered by a holding company which argued for retention of two integrated systems, one in Virginia and North Carolina and the other in Texas and Louisiana, on the ground that each was located in a single state and states adjoining it. Interpreting the ambiguous clause in the light of Congressional intent reflected in the whole Act, the Commission held that the fashioning of compact systems susceptible of localized management and control required that additional systems be located in the same or adjoining states with the company's principal integrated system. ${ }^{19}$

In two decisions involving an electric power holding company, the Commission approved as a single integrated system properties serving an area of about 90,000 square miles, but refused to allow the system to expand. ${ }^{20}$ Thus the Commission (x941).

${ }^{27} 8$ S.E.C. 443 (194r). See also the appendix to United Gas Improvement Co., 9 S.E.C. 52,77

${ }_{18}$ American Waterworks \& Electric Co., 3 S.E.C. 76 (1938).

${ }^{10}$ Engineers Public Service Co., 9 S.E.C. 764 (r94I).

${ }^{20}$ American Gas \& Electric Co., 2 I S.E.C. 575 (I945), 22 S.E.C. 808 (1946). 
made clear that mere size, per se, would not bring condemnation upon a system, but that what it would permit to survive it might not allow to develop.

A holding company system may also retain "such other businesses as are reasonably incidental, or economically necessary or appropriate" to its operations. The Commission has required the holding company to show that non-utility properties have a distinct functional relationship to its principal business. ${ }^{21}$ Thus one company was allowed to retain a coal company whose mines were used to supply a subsidiary utility, and an eleven mile railroad used to transport the coal to the utility; but a coal mine whose output had not been used by a system utility in 35 years was ordered divested. ${ }^{22}$ The miscellaneous character of the holdings of some systems is indicated by other divestments of the same company, which included parking lots and gas stations, a warehouse, and an amusement park. Arguments based on long association, profitability of interconnection, economies from joint personnel, etc. were not accepted. ${ }^{23}$ A contemplated future functional relationship, however, has been held to be enough. ${ }^{24}$ The Commission has declined to accept a distinction between "investments" and properties which were "operated" by the holding company. ${ }^{25} \mathrm{~A}$ second general requirement is that the holding company make an affirmative showing that consumer rates will be favorably affected by the retention of non-utility properties. ${ }^{26}$

\section{B. Corporate Reorganizations}

It was inevitable that many companies subject to the Act should have to undergo reorganization, some to meet the requirements of Section II, others to obtain Commission approval of securities issues, and still others because the financial condition of the company left no alternative. The latter reason is significant: many reorganization proceedings under Section Ir would have been mandatory in some form in any event to restore the financial health of the corporations involved. Between September, I929 and April, I936, 53 utility holding companies and $3^{6}$ utility subsidiaries went into receivership or bankruptcy. During the same period, 23 holding companies and 16 operating companies defaulted on interest and offered readjustment plans. ${ }^{27}$ The statistics on arrearages in preferred stock dividends were equally depressing. ${ }^{28}$

No reorganization of a company subject to the Act can escape the surveillance of the Commission. ${ }^{29}$ A corporate reorganization is a delicate and complex undertaking, frequently involving responsibility to thousands of persons who are unable

${ }^{21}$ United Gas Improvement Co., 9 S.E.C. 52 (194r), $a f^{\prime} d, 138$ F. $2 d$ roro (3d Cir. I943).

22 The North American Co., II S.E.C. 194 (1942).

${ }^{23}$ Id. at 2 12-I3.

2l Panhandle Eastern Pipe Line Co. v. SEC, I7o F. 2d 453 (8th Cir. I948).

${ }^{25}$ United Gas Improvement Co., supra note $2 \mathrm{r}$.

20 North American Co., supra note 22, at 220.

${ }_{27}^{27}$ Io SEC ANN. REP. 86-87 (1944).

${ }^{28} 6$ SEC ANN. REP. 40-4I (I940).

${ }^{29}$ North American Co. sought to dissolve a subsidiary in a Delaware court, but submitted to the jurisdiction of the Commission when the latter sought a federal injunction against the effectuation of the plan. 9 S.E.C. 6ri (r94I). 
adequately to defend their rights. For this reason, the Act provides that both the Commission in approving and the district court in enforcing an II (e) or II $(f)$ plan must find not only that it is appropriate to effectuate the purposes of Section II but that it is "fair and equitable to persons affected by such plans." This section of this paper will discuss interpretations of the terms "fair and equitable" which, in determining the respective rights of investors, have had the effect of increasing the fiduciary responsibility of holding companies for their management of their subsidiaries' affairs.

One such interpretation concerned the status to be granted to an intercompany debt claim in a reorganization proceeding. Ordinarily, a debt claim enjoys priority over the claims of any class of stock, but where it had been contracted by a subsidiary in a transaction with its parent not conducted at arm's-length, it was subject to question. When confronted with claims built up through some process of "milking" the subsidiary, the Commission has followed the "Deep Rock" principle established by the Supreme Court. ${ }^{30}$ The principle is that a parent corporation may not participate on the same basis as the public security holders in the reorganization of a subsidiary when it has been guilty of mismanagement or of unfairness to the subsidiary, but must subordinate its debt claims against the subsidiary to the claims of publicly held preferred stock. In practice, this has meant that the validity of the parent's debt claim and its right to priority must be determined in each case upon its merits. ${ }^{31}$ An effort in I94I to formulate a general rule was unsuccessful. ${ }^{32}$

The other interpretations of the words "fair and equitable" in reorganization plans that are important are those concerning the priorities to be assigned to the rights of various groups of security holders to participate in the new company. In early cases the Commission followed the doctrine of North Pacific Ry. v. Boyd, decided in $x 913$, that the assets of an estate must be divided among security holders, as far as they will go, in accordance with their contract rights and priorities. ${ }^{33}$ The strict adherence to contractual priorities followed in these cases, ${ }^{34}$ in which reorganizations under the Bankruptcy Act were reviewed pursuant to Section II $(f)$ of the Holding Company Act, has been modified by a distinction which the Commission now makes between equity receiverships and certain kinds of $\mathrm{rr}(\mathrm{e})$ re-

${ }^{30}$ Taylor v. Standard Gas \& Electric Co., 306 U. S. 307 (I939).

${ }^{31}$ In Pepper v. Litton the Court said: "The essence of the test is whether or not under all the circumstances the transaction carries the earmarks of an arm's length bargain. If it does not, equity will set it aside." 308 U. S. 295, 306-307 (1939). Cf. Consolidated Rock Products Co. v. DuBois, 3I 2 U. S. 510 (r94I).

${ }^{32} 7$ SEC ANN. Rep. I08-I09 (I94I). For representative cases, sec Mountain States Power Co., 5 S.E.C. I (1939); Gulf Public Service Co., 7 S.E.C. 1026 (1940); Appalachian Electric Power Co., 8 S.E.C. 27 I (I940); Georgia Power Co., 8 S.E.C. 656 (I94I); and Empire Fuel \& Gas Co., II S.E.C. 943 (I942).

${ }_{33}^{228}$ U. S. 482 ; accord, Case v. Los Angeles Lumber Products Co., Ltd., 308 U. S. 106 (1939). Cf. Consolidated Rock Products Co. v. DuBois, supra note $3 \mathrm{I}$.

${ }^{34}$ United Telephone \& Electric Co., 3 S.E.C. 653 (1938); West Ohio Gas Co., 3 S.E.C. 1014 (1938); Mountain States Power Co., 5 S.E.C. I (1939); United Light \& Power Co., 13 S.E.C. I (1943), aff'd in Otis \& Co. v. SEC, I42 F. 2d 411 (3d Cir. 1944), aff'd, 323 U. S. 624 (I945). 
organizations. ${ }^{35}$ If the appropriate order which the Commission must issue under II(b) is to liquidate, the II(e) plan is a substitute for liquidation; it is essentially the same proceeding as that under the Bankruptcy Act or an earlier equity proceeding, and liquidation preferences should be followed strictly. But if the appropriate order does not require liquidation, but reorganization to conform with II(b) requirements, the context is different: liquidation is not "in the air" and the contractual rights of various classes of security holders are not the same as if liquidation were imminent. If a class of common stock has reasonable expectation of participation in future earnings if the corporation were left undisturbed, it has a right to participate in the reorganization. If it has no such reasonable expectation, it may be extinguished without compunction. The principle is that "fair and equitable plans should not cause any class of securities to sacrifice valuable rights and confer a windfall on another class." 36 The principle is applied also in the Commission's refusal to approve the payment of redemption premiums on bonds and debentures when to comply with Section II it is necessary to eliminate or reduce debt. Since the retirements are not voluntary, it is held that call premiums cannot properly be claimed. $^{37}$

\section{Impact of Section II}

Some conception of the importance of the foregoing interpretations, and of the impact of Section II on the industry, can be had from the bare statistics of the Commission's performance. The Commission commenced its serious efforts to carry out the purposes of the section in 1940, and at the end of only twelve years it could say that the task was rapidly nearing completion. At one time or another in that period, 2x97 companies had been subject to the Commission's jurisdiction as components of registered holding company systems, 214 of these being holding companies, 929 electric or gas utilities, and 1054 non-utilities or utilities other than electric or gas. By the end of the fiscal year 1952 , the Commission had released 1760 companies from its jurisdiction, $76 \mathrm{I}$ by divestments under Section $\mathrm{II}$ and the balance through dissolutions, mergers, consolidations, exemptions, and other means. In addition to the divested properties released from Commission jurisdiction, 259 companies (I29 electric utility, 42 gas utility, 88 non-utility) were divested from one system in the process of integration and simplification but remained under control of another registered holding company. ${ }^{38}$ In the next year divestments increased to 812 companies with assets of $\$ \mathrm{II}, 497,536,97 \mathrm{I}$, of which I5I were gas utilities with assets of $\$ 738,171,23^{3} .{ }^{39}$ With the completion of its gigantic assignment under

${ }^{36} \mathrm{~A}$ full discussion of the distinction and supporting reasons is found in Federal Water Service Corp., 8 S.E.C. 893 (I94 $x$ ). The legal history of reorganization proceedings is found at 904-14. Commissioner Healy disagreed with the majority and until his death in 1946 continued to do so.

${ }^{30}$ ro SEC ANN. REP. 93 (I944).

${ }^{37}$ North Continent Utilities Corp., 54 F. Supp. 527 (D. Del. 1944); Consolidated Electric \& Gas Co., 55 F. Supp. $21 x$ (D. Del. 1944); Laclede Gas Light Co., 57 F. Supp. 997 (E.D. Mo. 1944); New York Trust Co. v. SEC, I3I F. 2d 274 (2d Cir. 1942), cert. denied, 318 U. S. 786 (1943); City National Bank \& Trust Co. v. SEC, 134 F. 2d 65 (7th Cir. 1943).

${ }_{38} 18$ SEC ANN. REP. 82-85 (I952).

${ }^{30}$ Ig SEC ANN. REP. 53 (1953). 
Section II in sight, the Commission already had passed into the next phase, the continuing supervision of the 20 holding company groups with aggregate assets of over seven billion dollars that were expected to remain as permanent integrated utility systems. Eighteen per cent of natural and manufactured gas plants would remain under holding company control, as contrasted with 28 per cent in the early thirties. ${ }^{40}$

In its report to the Senate, the Federal Trade Commission gave significant information on nine principal natural gas systems. ${ }^{41}$ Three of them offered little difficulty under Section II; one already was an integrated system and the other two soon effected mergers which eliminated their holding companies. The other six presented problems of real magnitude. Four of them, it will be remembered (supra, p. 456), dominated the industry. The story of what happened to any one of these giants perhaps would be the best way to epitomize the complex history of the Act. ${ }^{42}$ The proceedings have been long and complicated for several reasons. The Commission will not release a company from its jurisdiction until the latter has complied fully with the Act. This usually requires a piecemeal dismantling of a complex structure, in order to protect the rights of all who have an interest in each corporate entity. The Commission has been careful to avoid the wholesale dumping of utility assets on the market, as predicted by opponents of the Act prior to its passage. At each step of the way, questions such as those discussed earlier have had to be answered. There is room here for only the most summary statment of what happened to each system, but that should at least suggest the changes that have been made.

The largest holding company system ever registered under the Act was Electric Bond and Share Co., which in I938 controlled r21 domestic subsidiaries, including five major subholding companies. Three of the latter have been or will be dissolved. A fourth independently controls an integrated system. Bond and Share, which is to become an investment company, retains an interest in the fifth, which operates only in foreign countries. The sprawling Bond and Share empire has been replaced by numerous integrated systems, including that of United Gas Corporation (which was the system's principal natural gas sub-holding company) along the Gulf Coast in which Bond and Share now has less than five per cent interest.

Standard Oil Co. (New Jersey), faced with a choice between its gas utility and non-utility petroleum business, elected to divest the former. Accordingly, Standard's gas subsidiaries were transferred to Consolidated Natural Gas Co., a newly organized registered holding company, in return for all of Consolidated's capital stock, which then was distributed as a dividend to Standard's common stockholders. Standard ceased to be a holding company under the Act.

${ }^{10}$ I 8 SEC ANn. Rep. IIo (1952). III-XI.

1 Utility CoRporations, SEN. Doc. No. 92, No. 84-A, supra note 2, at 228-237, and maps

« Because of the multiplicity of orders and actions involved in bringing each system into compliance with Section II, citations will not be given here. Useful progress reports on each system may be found in the Commission's annual reports. 
Cities Service Co. at the time of its registration in I94I was the top holding company in a system made up of 125 companies with consolidated assets of approximately a billion dollars. Three sub-holding companies controlled the 49 electric and gas utilities in the system. Of those three, two have been liquidated and dissolved, and the third has divested its utility properties, remaining a subsidiary of Cities. In the near future, Cities itself should be no longer subject to the Act, having effectuated its plan to divest all its utility properties.

The fourth giant system, Columbia Gas and Electric Co., chose to continue as a registered holding company with an integrated natural gas system. A system sub-holding company sold its interest in Panhandle Eastern Pipe Line Co., and by I946 the divestment of electric utility properties was complete. Columbia Gas System, Inc. (as it is now named) operates in seven states and the District of Columbia, with total assets of approximately a half billion. Columbia owns all outstanding securities of its subsidiaries, and public financing of them is handled at the holding company level. The soundness of the system's condition was attested by the ease with which a huge construction program, beginning in 1950 , was financed.

The other two of the nine systems described by the Federal Trade Commission have had quite different histories under Section Ir. One of them, Lone Star Gas Corp., was the first major holding company system to comply completely with the requirements of the section. When it was released from Commission jurisdiction in 1944, it consisted of a Texas corporation engaged in transmission and distribution, with a single producing subsidiary. Approximately $\$ 20,000,000$ of questionable items had been eliminated from its property accounts, and its capitalization consisted of bank loans and a single system of common stock. Standard Gas and Electric Co. (and its parent, Standard Power and Light $\mathrm{Co}_{\text {.). }}$, on the other hand, has presented a maximum of difficulties. In 1936 the system represented in an extreme degree the pyramiding and scatteration of properties condemned by Congress, with ro5 companies operating in 20 states and Mexico, including nine registered holding companies. By the end of June, r952, it had been reduced to thirteen companies, of which six were utilities. Nevertheless, the problems have been complex and many remain; in I95I the Commission allowed the two top holding companies to withdraw $\operatorname{II}(\mathrm{e})$ plans approved in the mid-forties because conditions had changed before they could be consummated, and progress is being made in carrying out new plans.

\section{III}

\section{Other Provisions}

\section{A. Public Utility Security Issues}

The provisions of Section II call for the Commission to perform corporate surgery more or less against the patient's will. Most of the other sections of the Act outline a kind of continuing therapy designed to keep the patient well, whether 
he likes good health or not. One of the most effective of these measures is the power vested in the Commission to control the issuance of securities by corporations subject to the Act. Section 7 (d) provides certain qualitative standards which a security issue must meet to be approved by the Commission. Among other things, the security must be reasonably adapted to the security structure and earning power of the declarant; the financing represented by this security must be necessary or appropriate to the economical and efficient operation of a business in which the applicant lawfully is engaged or has an interest; the fees, commissions, or other remuneration paid in connection with the issue or sale of the security must be reasonable; and the terms and conditions of the issue or sale must not be detrimental to the public interest or the interest of investors or consumers. Section $7(\mathrm{~g})$ provides that state laws must be complied with; if the Commission is informed by state authorities having proper jurisdiction that they have not been complied with, approval must wait upon compliance. An issue or sale of securities may be exempted under several conditions, set forth in Section 6(b), the most important being that the securities are solely for the purpose of financing the business of a subsidiary of a registered holding company and have been expressly authorized by the state commission of the state in which the subsidiary company is organized and doing business. But to these exempted issues and sales the Commission may attach terms and conditions in the public interest or for the protection of investors and consumers.

A primary objective of the Commission in passing upon declarations filed with it has been to help companies subject to the Act to achieve balanced capital structures with a substantial proportion of common stock equity. One of the chief "evils" against which the Act was directed was the financing of utilities almost entirely through bonds and preferred stock sold to the public, the common stock exercising control representing a small part of total capitalization and little or no investment. A capital structure so composed lacks the "cushion" against adversity afforded by a proper amount of common stock, the corporate function of which is to absorb the losses as well as the gains. Furthermore, the rigid fixed charges associated with debt make it impossible for the company to adapt its financial program to changed conditions if debt makes up too great a proportion of its capital structure.

The Commission has been interested not so much in the amount of the debt as in the debt ratio-the ratio of bonds, or of bonds and preferred stock, to total capitalization and to net tangible property. It has also considered the relationship of earning power to the fixed charges of debt and the dividend requirements of preferred stock. The Commission has sought to limit funded debt to 50 per cent of the net fixed assets of the company, and the issuance of new additional bonds to 60 per cent of the cost or fair value, whichever is less, of net additions to fixed property. The higher ratio allowed for bonding additions is intended to give greater flexibility under the company's mortgage indenture to meet unforeseen future 
conditions. ${ }^{43}$ These conservative debt ratios may be contrasted with the 70 to 80 per cent of the fair value of additional property which had been customary in the utility industry.

The Commission has not attempted to devise a rigid set of standards, but rather to help each company to meet the requirements of the Act, using any tool available to solve each problem in its own factual context. The capitalization of subsidiary companies may be improved by capital contributions of parent companies, ${ }^{44}$ or by conversion of open accounts and senior securities of parents into common stock of subsidiaries (serving the further purpose of making them junior to publicly held bonds and preferred stock). ${ }^{45}$ In some instances common stock also has been sold to the public. Where these measures have proved to be impossible, or inadequate by themselves, requirements for systematic debt reduction have been incorporated in the mortgage indenture. This may be accomplished by sinking fund requirements, by restrictions on the payment of dividends out of earnings until certain debt retirement specifications have been met, and by serial financing. ${ }^{46}$ Write-ups have been eliminated from property accounts. Depreciation and maintenance funds have been increased to protect the integrity of capital.

Until the end of 1940, a majority of the Commission made a distinction between a security issue for the purpose of refunding outstanding obligations at more advantageous terms and one which created new debt. The majority's attitude was that a refunding issue which did not substantially improve an already bad capital structure, but which reduced the interest burden and provided for systematic debt reduction, might be justified as a "step in the right direction." This attitude was consistently opposed by Commissioner Robert E. Healy, who believed that when the Commission considered a declaration filed by a company whose top-heavy capital structure reflected the kind of practices Congress had branded as an evil, its plain duty was to require a change in the capital structure forthwith. The conflicting opinions were expressed vigorously in early opinions. ${ }^{47}$ The viewpoint of Commissioner Healy was to prevail. In El Paso Electric Co. ${ }^{48}$ the Commission specifically reversed its policy, requiring henceforth that all security issues, irrespective of purpose, meet the standards of 7 (d).

${ }^{43} 7$ SEC ANN. REP. 97-98 (194I).

"Appalachian Electric Power Co., 8 S.E.C. 27 r (1940).

${ }^{4}$ Gulf Public Service Co., 7 S.E.C. 1026 (I940); Georgia Power Co., 8 S.E.C. 656 (I94X).

10 Public Service Co. of Colorado, 5 S.E.C. 788 (1939). These requirements are summarized in 13 SEC ANN. Rep. 89 (1947).

${ }^{47}$ The distinction between refunding and new financing was made explicit by Commissioner Jerome Frank in a separate concurring opinion in Southwestern Gas \& Electric Co., 6 S.E.C. 806, 822 (1940). Commissioner Healy's position is put forthrightly in Public Service Co. of Colorado, supra note 46, where, after adjusting net assets by deducting write-ups and intercompany profits, he figured that bonds and debentures then approved, plus preferred stock, would account for ror.22 per cent of the company's net assets. See also Republic Service Corp., 2 S.E.C. 44 (1937); Peoples Water \& Gas Co., 3 S.E.C. 430 (1938); Consumers Power Co., 6 S.E.C. 444 (1939); West Penn Power Co., 7 S.E.C. 69 (1940).

ss 8 S.E.C. 366 (1940). An appendix to the opinion (at p. 383) gives comprehensive reasons for the change in policy. 
Some measure of the success of the Commission, both in achieving balanced capital structures and in making public utility issues attractive to investors because of the conservative nature of the underlying capital structures, may be had from even a brief account of financing under the Commission's jurisdiction. In the period from November I, I935 to the end of the fiscal year 1944, nearly 70 per cent of the issues were for refunding, yet the Commission was able to keep the proportion of long term debt below 60 per cent. In I945 and I946, many corporations which had refunded in the early years of the Act's administration were able to refund again, at an additional saving. With the hardening of money rates and the beginning of a tremendous utility expansion program, the emphasis shifted to new financing; in 1952 virtually all of the issues represented new money, as contrasted with less than one per cent in $1945 .{ }^{49}$ Security offerings under the Act reached their peak in 1950, but despite the steady contraction of systems subject to Commission jurisdiction the decline since then has been slight, so great is the volume of construction. $^{50}$ What is perhaps most striking is the large proportion attributable to common stock offerings, which accounted for 30.8 per cent of the total in 1950.51 Where many holding companies once financed their subsidiaries through high interest loans, they now purchase common stock of their subsidiaries; and as the flow of money from divested properties tapers off, they sell their own common stock to the public. Capitalization of holding companies generally is limited to debt and one class of common stock.

Requirements designed to assure equitable voting rights to all classes of stockholders are nearly ubiquitous in the Commission's decisions on security issues. Most of them are safeguards for the rights of preferred stockholders, who otherwise might be forced to suffer arrearages in dividends at no great inconvenience to common stockholders. They have been tailored to fit individual problems, but the principal provisions may be summarized briefly. ${ }^{52}$ Upon defaults in payment of preferred dividends aggregating one year, the preferred stock as a class is given the right to elect a majority of the board of directors. The control returns to common stock upon the payment of the arrearages. The issuance of unsecured debt in excess of Io per cent of the aggregate secured debt, capital, and surplus of the company must be approved by a majority vote of the preferred stock. Preferred stock must approve by a two-thirds vote the issuance of any new preferred stock with rights prior to its own. If common stock equity is or becomes less than 25 per cent of total capitalization and surplus, dividends on common stock are automatically restricted. No change in the terms and conditions of outstanding stock which is substantially prejudicial to the preferred stockholder may be made without two-thirds approval by preferred stock. In addition to protecting preferred stock, the Commission has established nomination and election procedures intended to effectuate the will of all stockholders having a voice in control.

19 I8 SEC ANn. Rep. I27 (1952).

6I I7 SEC ANN. Rep. I08 (195I).
${ }^{50}$ xg SEC ANn. Rep. 74 (1953).

${ }^{2}$ I3 SEC ANN. REP. 90-9I (1947). 
In April, 194I, the Commission adopted Rule U-50, which requires that securities of registered holding companies be offered at competitive bidding. ${ }^{53}$ This ended the common practice of negotiating the sale with a single principal underwriter, who frequently was affiliated with the holding company. The competitive bidding rule has had two clear results. One is that the cost of handling utility mortgage bond issues has sharply declined. The underwriting spread for 159 issues sold in the five year period ending January $I$, I940 by private negotiation was 2.49 points (\$2.49 per \$100). In only four cases was the spread below two points. In a similar period ending June 30, r949, of I79 issues sold at competitive bidding, three-fourths had a spread of seventy-five cents or less, and only eight went at $\$ 1.25$ or more. ${ }^{54}$ A second is that a more diversified management of security offerings now prevails. In the same five year period, in a study of 24 companies offering securities at competitive bidding on at least four occasions, there was only one instance of a single underwriter winning all of a company's issues. Eleven were handled by four managers, and eleven by three..$^{55}$

In the spring of 1954 the Commission held two public hearings to consider an amendment to Rule U-5o which would grant to state-authorized security issues of subsidiaries of registered holding companies an automatic exemption from the Commission's competitive bidding requirements. The arguments of proponents fell into two categories. The first was confined to the question at issue. It was urged that the Commission's administration of Sections II and I7(c) (barring bankers from offices or boards of registered holding companies and their subsidiaries) had "immunized" the regulated companies from the abuses at which the rule was directed. Moreover, the exemption was limited to issues approved by state authorities, which would strengthen local regulation in accordance with the basic purpose of the Act. The second category of arguments attacked the rule itself, claiming that "banker domination" was a myth, and that without the continuing advice of the investment banker real losses were sustained from offering the wrong securities at the wrong place at the wrong time. The opponents of the amendment contended that compulsory competitive bidding was necessary to preserve arm's-length bargaining and free competition. They pointed to the substantial economies in financing attributed to the rule by the Commission in its annual reports through the fiscal year 1952, and asked what changes in utility economics had occurred since then. In early May, the Commission had not announced its decision.

\section{B. Service Company Regulation}

A very large source of profit to public utility holding companies prior to I935 was the performance of various services at a charge for the subsidiary companies in their systems. To end the exploitation shown to be a frequent product of these unilateral transactions, Congress provided in Section 13 of the Act, generally speaking,

\footnotetext{
${ }^{53}$ For the events and considerations leading to the adoption of the rule, see 7 SEC ANN. REP. 98102 (194I).

54 Y5 SEC ANN. REP. 88-89 (1949).

${ }^{25}$ Id. at 89 .
} 
that a registered holding company could not perform services or construction work for, or sell goods to, the companies in its system, and that the subsidiary companies, mutual service companies, ${ }^{56}$ and independent companies which could do so must comply with rules and regulations to be laid down by the Commission. The Commission was to insure that all such services should be performed economically and efficiently for the benefit of the companies served, and at cost, fairly and equitably allocated among the companies served.

Holding companies accordingly terminated their services to their subsidiaries and formed system service companies to comply with the Act. These were qualified as rapidly as possible by the Commission, after which it was necessary to scrutinize their organization and operations with care to shape them to the law's requirements. The problem was that no two service companies performed quite the same group of services and few called identical activities by the same name. The Commission began by requiring uniform accounts and annual reports, after which, in the case by case pragmatic approach characteristic of its operations, it had to learn enough about service company operations to develop principles to go by. ${ }^{57}$

The most difficult problem encountered in the administration of Section ${ }_{3} 3$ was presented by interlocking officer arrangements in holding companies and their subsidiary service companies. Policies in regard to the payment of the salaries of common officers varied, but in the absence of free bargaining the holding company's share usually was quite small.5s Thus the holding company seemed to circumvent the law's prohibition on the sale of services to a subsidiary. There was a question also whether the common officers could serve both operating and holding company with equal zeal. Furthermore, the principal service performed was general management, an exercise of the control function which should be paid wholly by the parent out of the dividends received from operating company stock.

The formulation of the policy on interlocking officers began with an opinion on Ebasco Service Company, which had been formed in 1935 to take over servicing activities performed by Electric Bond and Share for its subsidiaries since 1906.50 Ebasco was controlled by six directors and officers who held identical positions in Bond and Share. The Commission ruled that the common officers must sever their relations with one or the other company, or that their entire salaries should be paid by the parent. Earlier decisions approving interlocking officer arrangements of this kind were overruled as precedents. But the variety of devices employed by different companies required individual scrutiny. One service company paid all the salaries of officers and employees of holding and sub-holding companies on its payroll, then charged system companies on the basis of time devoted to the service of each. The Commission required the parent to pay the salaries of all persons whose work pri-

\footnotetext{
E* The difference between the two types of companies is that the capital for subsidiary companics is supplied by the parent company, while the capital for mutual service companies is furnished by member companies. A holding company system may include either.

${ }^{57} 6$ SEC ANN. REP. 45-47 (1940).

6s 7 SEC ANN. REP. IIO-III (I94I).

${ }^{69} 7$ S.E.C. 1056 (I940). Cf. Middle West Service Co., 9 S.E.C. 91 (194r).
} 
marily benefited it. ${ }^{60}$ A similar ruling was made where common officers were paid out of a separate "Treasurer's Account" (reimbursed by the system companies), and a "split-check" arrangement (a separate check from each company for its share of each common officer's salary) that was substituted for it met a similar fate. ${ }^{61}$ In requiring that several whole departments, as well as individual officers, be moved from a service company into the top holding company, the Commission held that it was the function of the officer or employee in question rather than the position held or situs on a particular payroll that should determine whether he was a holding company officer or employee. ${ }^{62}$ In this case the Commission enunciated the standards toward which it had been moving. Briefly stated, they prohibited the charging of an operating company, through any device, for any part of the salary of a person engaged primarily in the holding company's function of supervision; they barred such person from receiving compensation from operating companies; and they required service companies to confine themselves to services of an "operating nature" which operating subsidiaries could not perform as efficiently and economically themselves.

The requirement that services be rendered at cost fairly and equitably allocated among the companies served has caused the Commission to scrutinize closely the capitalization, expense items, and cost charge systems of companies subject to the Act. The cost of rendering service consists primarily of the expenses of the service company, 60 to 70 per cent of which is salaries. The Commission has included "reasonable compensation" for necessary capital as a legitimate charge on the companies served, but limits the amount of capitalization to prevent the transfer of idle funds to service companies where they contribute nothing to the performance of services. ${ }^{63}$ Outside investments usually must be liquidated, although there are exceptions. There is no limitation on capitalization, of course, where the parent asks no return on capital invested in the business. Working capital is limited to a ratio of a month's expenses. The ratio varies; usually it ranges from $2-I$ to $3-\mathrm{I}^{64}$ Since the Ebasco case, the rate of return, where a return on capital is claimed, has been 4 per cent. The general rule for the allocation of costs seems to be that, in so far as it is possible, direct charges shall be made for particular services rendered, with the overhead allocated as fairly as possible. The cases show a progressive refinement in cost allocation schemes.

It seems safe to say that the major problems in the administration of Section 13 have been solved. The Commission appears now to regard it as routine administration; not since I944 has an annual report contained a section on service company regulation. Indisputably, the regulation under this section has had a profound effect on the conduct of the public utility industries. In a sense, the service com-

${ }^{\circ 0}$ United Light and Power Service Co., 8 S.E.C. 738 (x94r).

${ }^{21}$ New England Gas \& Electric Ass'n, 12 S.E.C. 12 (1942).

es Columbia Engineering Corp., 12 S.E.C. 922 (1943). Cf. Public Utilities Management Corp., I3 S.E.C. 532 (I943); Federal Advisers Inc., I3 S.E.C. 632 (r943).

${ }^{3}$ Ebasco Services, Inc., 7 S.E.C. 1056, 1072 (1940).

ot Id. at ro72-74. See also Columbia Engineering Corp., I2 S.E.C. 922, 943 (I943); American Water Works and Electric Co., 14 S.E.C. 924, 942 (1943). 
pany racket, while not the most spectacular, probably was the meanest of the holding company abuses; it was the fillip that added insult to injury: an operating company exploited to the verge of bankruptcy still could be charged outrageously for the "service." This has come to an end. Service companies now must be genuinely useful organizations.

\section{IV}

\section{Conclusions}

The administration of the Holding Company Act has proceeded almost to the point where the Securities and Exchange Commission can close its files on the reconstruction phase of its work and confine itself to the continuing supervision of those companies which will remain subject to the Act. The record of achievement, put in the baldest way, is impressive. Holding company "scatteration" has been replaced by integrated systems which are in the process of consolidating their single region holdings. Corporate structures have been simplified and useless companies liquidated. Capital structures have been balanced, debts refunded, and financial health restored. Voting rights have been reallocated more fairly. Service companies have been made a source of savings to their associates, not of profits to holding companies. Interpretative decisions, the vertebrae of any statutory corpus, have been made courageously, in the spirit of the Congressional intent which framed the Act.

The administration of Section Ir, as it may be epitomized in the experiences of major natural gas systems, has resulted in: (I) the elimination of three of the "big four" of I935 from the natural gas holding company field; (2) the reduction of the fourth, divested of its control of a major pipe line company, to an integrated natural gas system in the Appalachian region; (3) the elimination of oil companies as public utility holding companies; (4) the divorce of major natural gas and electric power systems, and the disposal by gas systems of all electric utility holdings of any consequence; and (5) the termination of the drift toward concentration of control in super-holding companies.

The limitations of the Holding Company Act nevertheless should be kept in mind. First, it is largely self-liquidating legislation. It might be compared to calling in troops to meet an emergency: the intention is not to supersede local authority, but to restore conditions in which it can be effective. For this reason, the Commission has made full use of the provisions in the Act for cooperation with the states. Whether the corporate practices of utility holding company systems are regulated effectively in the future will depend largely upon the states. Second, the Holding Company Act affects public utility companies, but it is not public utility legislation. The Commission is not directed to establish holding company systems of optimum size and organization, nor is it empowered to order physical connections, nor to establish regional networks, nor to require fair rates and efficient service. Those are tasks for public utility commissions. The Securities and Exchange Commission has performed its task when utility holding company systems meet the 
standards of regional. integration and corporate simplification established by the Act.

It is tempting to find in the experience of the holding company legislation a panacea for numerous economic ills, real or fancied, and particularly for those of business monopoly. ${ }^{65}$ But generalizing from a single experience seldom is safe. In this instance especially, the administrative performance should not be lifted from its historic context. The Act was championed by a popular President in an era of reform, and the spectacular collapse of great "empires" made holding companies vulnerable. The President appointed zealous commissioners who believed in the Act, and by the time their handiwork reached the courts a friendly reception had been prepared for it. Yet it is well to remember that the President got less than he wanted, and even that by only one vote in the Senate. Furthermore, the decisive acts of administration could be and were performed before time began to run against the reformers. The passage and successful administration of so drastic an act would seem to require a very special political climate, which does not come often to this country. Indeed, there would seem to be few occasions requiring government to intervene so thoroughly in the conduct of private business, in an effort to restore an observance of rudimentary business ethics. What is salutary is the demonstration that positive corrective measures tailored to fit the factual situation can successfully be substituted for general prohibitions and negative sanctions. That would seem to be the point of the experience with the Holding Company Act, and what is most relevant for other areas of economic regulation.

${ }^{\mathrm{CE}}$ Hearings before the House Judiciary Subcommittee on Monopoly Power, Part 2-B, 8Ist Cong., Ist Sess. I3II-39 (1949). But see Trienens, The Utility Act as a Solution to Sherman Act Problems, 44 ILL. L. Rev. 33 (I949). Comment, Section $11(b)$ of the Holding Company Act-Fifteen Years in Retrospect, 59 YALE L. J. 1088 (1950). 
